PACS: $51.50 .+\mathrm{v}, 52.80 .-\mathrm{S}$

\title{
INFLUENCE OF ELECTRON INJECTION ON THE CHARACTERISTICS OF A HOLLOW CATHODE GLOW DISCHARGE
}

\author{
DStanislav V. Pogorelova, (DVolodymyr A. Timaniuk ${ }^{\mathrm{a}, *}$ \\ (N) Nikolay G. Kokodii ${ }^{\mathrm{a}, \mathrm{b}}$, ${ }^{\circ}$ Ihor V. Krasovskyia \\ ${ }^{a}$ National University of Pharmacy, Kharkiv, Ukraine \\ ${ }^{b}$ V.N. Karazin Kharkiv National University, Kharkiv, Ukraine \\ *Corresponding Author: vladimir.timaniuk@gmail.com, tel.: +38095 5053919 \\ Received January 18, 2021; revised March 31, 2021; accepted April 7, 2021
}

\begin{abstract}
The article presents the results of experimental studies of a glow discharge with a hollow cathode in helium and argon gases using an auxiliary discharge as an electron emitter. The authors proposed to make the electrode common for both discharges in the form of a cylindrical metal mesh. The advantage of this design is explained as follows. The connection between the discharges is carried out through holes in the grid with a geometric transparency of 0.2 , which makes it possible not only to smoothly control the glow discharge current, but also to enhance the discharge current. Plasma is known to be one of the most efficient electron emitters; however, its use as a cathode in devices with a glow discharge at low gas pressures is complicated by the fact that a grid with small holes is required to separate the electron flow from the plasma, and it is impractical to use such a system in view of low mechanical strength of the grid Since the hollow cathode works effectively at low gas pressures, the release of an electron flux from the plasma of some auxiliary discharge is possible with much larger holes in the grid separating the plasma and the hollow cathode cavity. In this case, the grid can be made such that it can withstand sufficiently high thermal loads and can operate in typical discharge modes with a hollow cathode. The injection of electrons into the cathode cavity of the glow discharge changes the radial distribution of the glow intensity, the width of the cathode dark space, and other parameters of the plasma in the cathode cavity. The influence of electrons penetrating from the auxiliary discharge into the cathode cavity of the main discharge becomes significant when the current of these electrons is comparable to or exceeds the current of electrons leaving the grid cathode surface as a result of $\gamma$-processes. In parallel with the measurement of the optical and electrical characteristics of the hollow cathode glow discharge plasma, measurements of the electron concentration were carried out by the microwave sounding method. The entire current of the auxiliary discharge penetrates into the cavity of the main discharge; however, after acceleration in the cathode dark space, the electrons penetrating from the auxiliary discharge ionize gas atoms and noticeably increase the current of the main discharge. Additional ions formed due to the ionization of the gas by the injected electrons knock out new electrons from the cathode surface, which makes it possible to increase the discharge current.
\end{abstract}

KEY WORDS: glow discharge, plasma, hollow cathode, electrons, injection.

The cathode material and conditions on its surface determine the cathode potential drop and, consequently, the discharge burning voltage [1]. The cathode potential drop is substantially determined by the efficiency of the processes of electron emission from the cathode, the totality of which is called $\gamma$-processes. The $\gamma$ coefficient numerically determines the efficiency of $\gamma$-processes and depends on the cathode material and the state of its surface [2].

In many cases of using the glow discharge the aim is to reduce the cathode potential drop. This is achieved by using more efficient elements as the cathode. It is known that plasma is one of the most efficient emitters of electrons; however, its use as a cathode in devices with a glow discharge at pressures below 1 torr is hampered by the fact that a very fine grid is required to separate the electron flow from the plasma, and such system is impractical due to the low mechanical strength of the grid [3], [8]. Since, as follows from our experimental data, the hollow cathode works effectively at low (less than 5.0 Torr) gas pressures, the extraction of an electron flux from the plasma of some auxiliary discharge is possible with much larger holes in the grid separating the plasma and the cathode cavity of the hollow cathode. In this case, the grid can be made such that it can withstand sufficiently high thermal loads and can operate in typical hollow cathode discharge modes.

\section{GOALS OF ARTICLE}

The discharge tube (Fig. 1), which implements the idea of a plasma hollow cathode, includes a cylindrical hollow cathode (1) with a diameter of $30 \mathrm{~mm}$ and a length of $100 \mathrm{~mm}$. The geometric transparency of the grid cathode is 0.2 , the hole diameter is chosen so that it is less than the width of the cathode dark space in the region of optimal pressures for the cathode of a given diameter. The anodes (2) of a hollow cathode discharge, which will be called the main discharge, are two annular electrodes located coaxially with the cathode at a distance of $10 \mathrm{~mm}$.

An auxiliary discharge is ignited between a cylindrical copper cathode (3) with a diameter of $90 \mathrm{~mm}$ and a grid cylinder (1), which plays the role of an anode in this discharge. Flat disks (4) made of insulating material shield the auxiliary discharge area from the main discharge anode in such a way that the connection between the discharges is carried out only through the holes in the grid. Even if there is no electric field in the cathode cavity of the main discharge, electrons from the anode region of the auxiliary discharge will penetrate through the holes into the grid cylinder cavity. Essentially, part of the metal surface of the hollow cathode in this design is replaced by the plasma generated in the auxiliary discharge. At a sufficiently high current of injected electrons, the main hollow cathode discharge should be considered as a non-selfsustained discharge. 


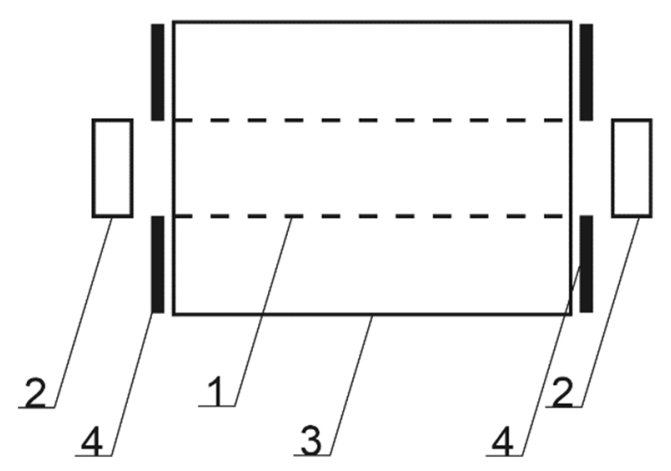

Figure 1. Construction of the discharge tube with a plasma hollow cathode: 1 - cathode of the main discharge, anode of the auxiliary discharge (grid); 2 - main discharge anodes; 3 - auxiliary discharge cathode; 4 - shielding discs.

\section{MATERIALS AND METHODS}

When the auxiliary discharge is ignited, electrons will be injected into the cathode cavity of the main discharge, which, passing through the holes in the grid cylinder, in the cathode plane of the main discharge will have thermal velocities, i.e., they are equivalent to secondary electrons knocked out of the metal by positive ions, light quanta and metastable atoms. In the cathode dark space of the hollow cathode, the injected electrons will be accelerated and create additional ionization in the cathode cavity, increasing the hollow cathode discharge current. Since the number of injected electrons depends on the auxiliary discharge current, it becomes possible to smoothly control the discharge current with a hollow cathode.

The characteristics of a discharge with a hollow cathode in the form of a grid cylinder do not qualitatively differ from the characteristics of a discharge with a solid cathode. The difference from a solid cathode is that the current-voltage characteristic of the discharge is steeper. This is apparently due to the losses through the holes of the grid of metastable atoms and photons regenerated in the negative glow.

As we can see from our experiments in helium (pressure range 0.2 - 10 Torr) and argon (pressure range 0.06 - 6 Torr) gases, the form of the dependence of the burning voltage on the pressure in the main hollow cathode discharge is determined by the motion of charged particles in the cathode cavity. A shift of the boundaries of the region of optimal pressures towards lower values is observed with an increase in the atomic mass of the gas and is due to the fact that the mean free path of electrons increases with a decrease in the atomic mass of the gas.

When the auxiliary discharge is switched on, electrons from the auxiliary discharge enter the cathode cavity through the holes in the grid. This leads to an increase in the main discharge current or, if the current is kept constant, to a decrease in the burning voltage of the main discharge. With an increase in the auxiliary discharge current, the burning voltage of the main discharge decreases, and the auxiliary discharge exerts its greatest influence in the region of optimal pressures for a hollow cathode discharge.

At high currents of the auxiliary discharge, a section where the combustion voltage of the main discharge is almost independent of the gas pressure appears on the curves. In this mode, the discharge with a hollow cathode becomes nonself-sustaining, the burning voltage of the discharge is substantially determined by the anodic potential drop.

\section{RESULTS}

The main discharge burning voltage reduction mechanism can be represented as follows (Fig. 2). Electrons injected from the auxiliary discharge into the cathode cavity enter the cathode dark space and decrease the positive ions space charge at the cathode. A decrease in the cathode potential drop and the number of ionizations performed by electrons in the cathode cavity is compensated by an increase in the effective value of the secondary emission coefficient $\gamma$.

With a decrease in the cathodic potential drop of the main discharge, the efficiency of gas ionization by additional electrons coming from the auxiliary discharge decreases. The analysis of the current-voltage characteristics of the simultaneously switched on main and auxiliary discharges shows that the degree of influence of the auxiliary discharge on the main one strongly depends on the main discharge current and increases with decreasing a hollow cathode discharge current (Fig. 3). Apparently, the influence of electrons penetrating from the auxiliary discharge into the cathode cavity of the main discharge becomes significant when the current of these electrons is comparable to or exceeds the current of electrons leaving the grid cathode surface as a result of $\gamma$-processes.

An analysis of the dependences of the main discharge current on the auxiliary discharge current for fixed voltages at the main discharge electrodes shows that the main discharge current increases, and more than the auxiliary discharge current increases (Fig. 4). Naturally, the entire current of the auxiliary discharge penetrates into the cavity of the main discharge; however, after acceleration in the cathode dark space, the electrons penetrated from the auxiliary discharge ionize the gas atoms and noticeably increase the current of the main discharge. Thus, in addition to controlling the main discharge current, current amplification is possible. 


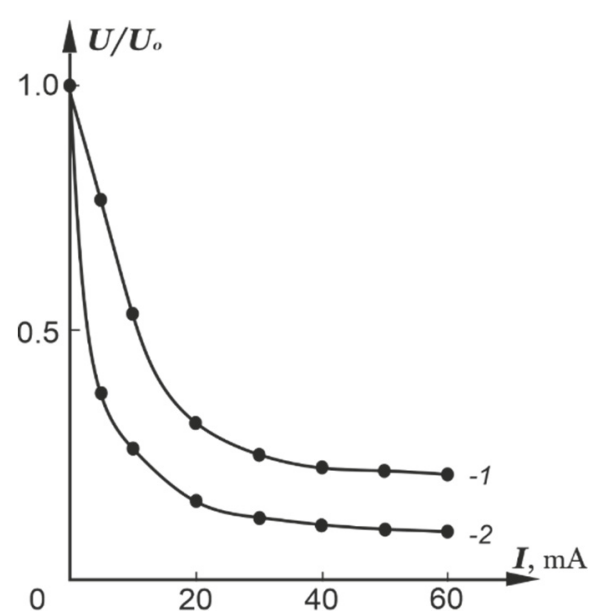

Figure 2. Dependence of the relative decrease in the main discharge burning voltage on the auxiliary discharge current at a pressure of 0.2 Torr. $I_{\text {main }}=10 \mathrm{~mA}, 1-\mathrm{He}, 2-\mathrm{Ar}$.

a)

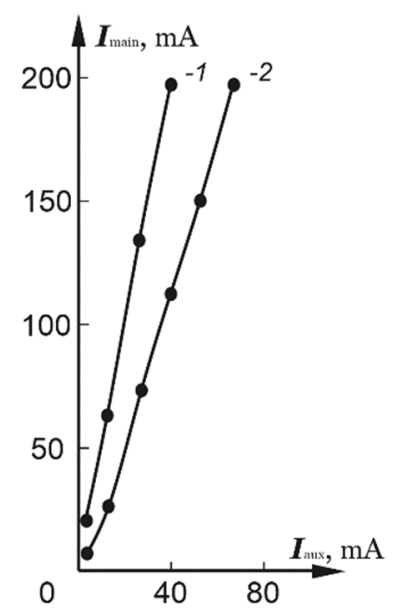

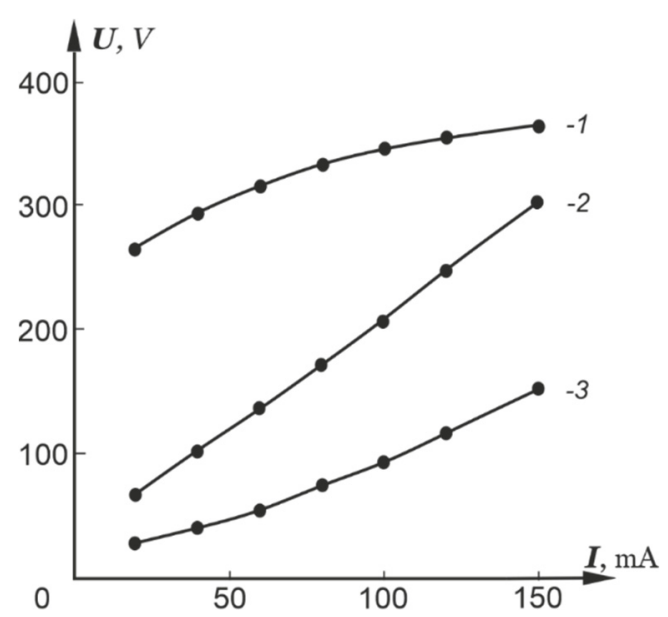

Figure 3. Current-voltage characteristics of the main discharge at various currents of the auxiliary discharge in helium at a pressure of 0.2 Torr. $1-0 \mathrm{~mA}, 2-20 \mathrm{~mA}, 3-50 \mathrm{~mA}$.

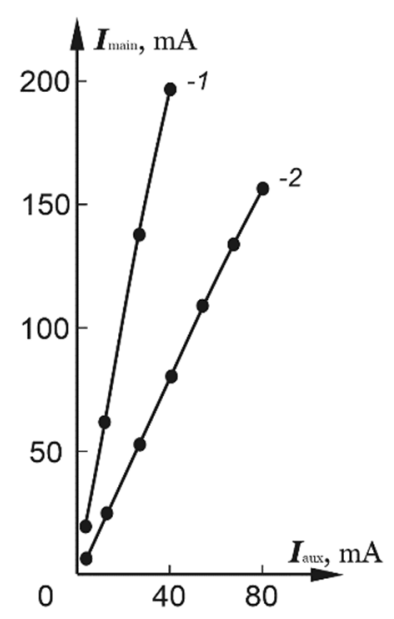

b)

Figure 4. Dependences of the main discharge current on the auxiliary discharge current at a pressure of 0.2 Torr. a) $\mathrm{He}, 1-U_{\text {main }}=125 \mathrm{~V}, 2-U_{\text {main }}=100 \mathrm{~V}$; b) $U_{\text {main }}=125 \mathrm{~V}, 1-\mathrm{He}, 2-\mathrm{Ar}$.

The first ionization potential of a helium atom is approximately 1.6 times greater than the ionization potential of, for example, argon atoms, and one might assume that the gain should decrease with decreasing atomic mass of the gas. However, the number of electrons knocked out due to the bombardment of the grid cathode surface by ions will be higher in helium, since the secondary emission coefficient in this case for helium is about 2.4 times higher than for argon. Consequently, the injection of additional electrons into the cathode cavity is most effective in a helium discharge.

Due to the penetration of ions from the cathode cavity of a hollow cathode discharge into the region of the auxiliary discharge, there is also a reverse effect of the main discharge on the auxiliary one. An auxiliary discharge is fired up between a coaxially located cylindrical cathode and an anode; therefore, there are no electron oscillations in the discharge gap and the discharge characteristics are practically the same as for a linear one. When the main discharge is ignited, some of moving towards the grid cathode ions penetrate through the holes into the auxiliary discharge space. Reaching the cathode of the auxiliary discharge, these ions cause the emission of secondary electrons, as a result of which the burning voltage of the auxiliary discharge also decreases.

The probability of additional ions reaching the auxiliary discharge cathode increases with decreasing gas pressure; therefore, at low gas pressures, the effect of the main discharge on the auxiliary discharge increases. In this case, main discharge ion current can be so significant that the burning voltage of the auxiliary discharge can become equal to zero, and even reverse its sign at high currents of the main discharge. The increase in the effect of the main discharge on the auxiliary discharge at high gas pressures can apparently be explained by an increase in the probability of recombination, as a result of which ultraviolet radiation quanta penetrating through the holes in the grid appear and produce additional ionization in the auxiliary discharge region, which leads to a decrease in the burning voltage of the auxiliary discharge. Effect of the main discharge on the auxiliary one is much stronger at low currents of the auxiliary discharge.

The injection of electrons into the cathode cavity of a hollow cathode discharge changes the intensity and radial distribution of the glow, the width of the cathode dark space, and other parameters of the plasma in the cathode cavity. 
Visual observations of the discharge glow in a plasma hollow cathode show that at a pressure corresponding to the upper boundary of the region of optimal pressures, the glow, which at higher pressures has a ring shape, fills the axial region of the cathode cavity. This fact once again confirms that the manifestation of the effect of the hollow cathode consists in the interaction of the opposite sections of the cathode.

Using a photomultiplier tube, which, movable along the end of the discharge tube together with a system of collimating diaphragms, integral distributions of the glow intensity over the cathode diameter were obtained (Fig. 5). With an increase in the auxiliary discharge current, the diameter of the glowing region of negative luminescence increases, and the width of the region of the cathode dark space decreases, due to an increase in the current of electrons injected from the auxiliary discharge.

One of the features of a hollow cathode discharge is the anomalously low value of the width of the cathode dark space and its weak dependence on the gas pressure [4], [9]. The width of the region of the cathode dark space in the plasma hollow cathode was measured using the curves of the radial distribution of the glow intensity. In parallel with these measurements, the discharge glow from the cathode end were photographed. It should be noted that the results obtained using both methods of measuring the width of the region of the cathode dark space are in good agreement.

With increasing pressure, the width of the region of the cathode dark space decreases, and in the region of optimal pressures it practically does not change. The width of the region of the cathode dark space depends on the value of the cathode potential drop and on the space charge density of positive ions in the cathode dark space, and these values in a hollow cathode discharge depend on the gas pressure nonmonotonically. An increase in the auxiliary discharge current leads to a noticeable decrease in the cathode space, which is caused by a decrease in the space charge density due to the entry of electrons from the auxiliary discharge into the cathode dark space (Fig. 6). With decreasing pressure, the effect of the auxiliary discharge current on the cathode space increases, which can probably be explained by the fact that an increasing fraction of electrons, penetrating from the auxiliary discharge and accelerated in the cathode dark space, begins to leave the cathode cavity without spending all their energy on ionization of gas atoms; in addition, the ionization efficiency near the ends of the cathode decreases.

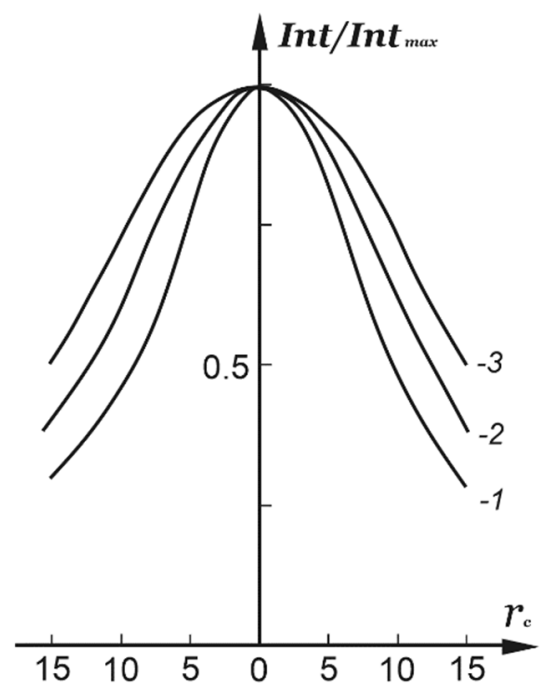

Figure 5. Normalized radial distributions of the main discharge glow intensity in helium $\left(P=0.2\right.$ Torr., $\left.I_{\text {main }}=30 \mathrm{~mA}\right)$. $1-I_{\text {aux }}=0 \mathrm{~mA}, 2-I_{\text {aux }}=10 \mathrm{~mA}, 3-I_{\text {aux }}=20 \mathrm{~mA}$.

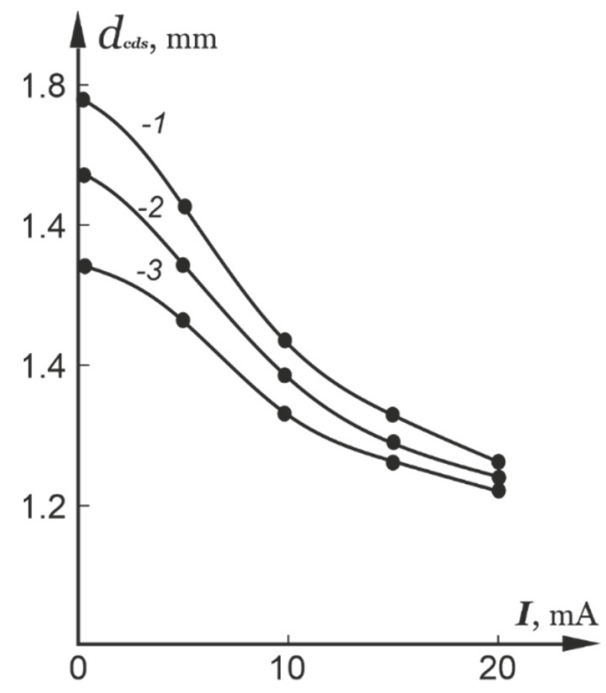

Figure 6. Dependences of the width of the region of the cathode dark space on the auxiliary discharge current in helium. $I_{\text {main }}=30 \mathrm{~mA}, 1-P=0.2$ Torr., $2-P=0.3$ Torr., $3-P=0.6$ Torr.

In parallel with the measurement of the electrical and optical characteristics of the plasma hollow cathode, the electron concentration in the cathode cavity was measured by microwave probing using wavelength of $3.1 \mathrm{~cm}$. It turned out that at a constant current of the main discharge, the electron concentration in the cathode cavity is almost independent of the auxiliary discharge current. A slight increase indicates a decrease in the axial electric field in the cathode cavity.

It is of interest to estimate the magnitude of the current of electrons injected from the auxiliary discharge into the main discharge cathode cavity. For this purpose, a metal cylinder with a length equal to the cathode length was introduced coaxially into the cavity of the hollow cathode, which was used to simulate the negative glow region. The dependence of the cylinder current on the cylinder-cathode voltage was obtained for various helium pressures at a fixed auxiliary discharge current (Fig. 7). The linear logarithmic dependence of the current in the deceleration mode indicates the Maxwellian distribution of the velocities of the electrons entering the cathode cavity from the auxiliary discharge. The temperature of these electrons in the investigated range is 5-7 eV. The total current of electrons injected into the cathode cavity can be determined from the inflection point of the curves and, for example, for a pressure of 0.3 Torr, it is about 4 $\mathrm{mA}$. With increasing pressure, the magnitude of this current decreases. A comparison of these results with the dependence of the main discharge current on the auxiliary current shows that the amplification of injected electrons in the cylindrical cathode cavity occurs by about an order of magnitude. 


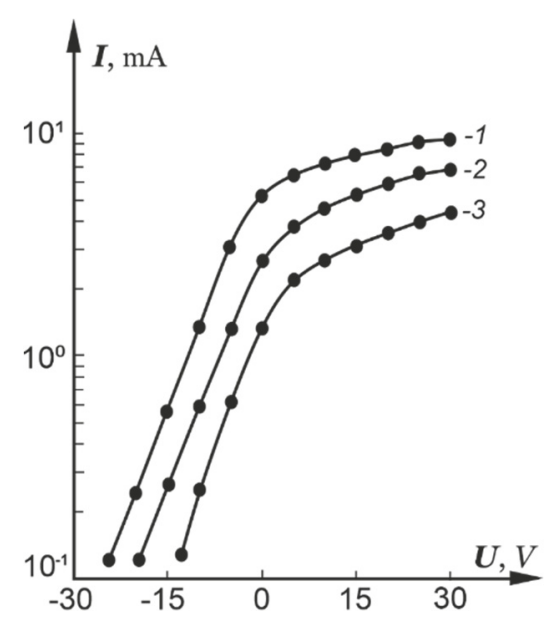

Figure 7. Dependences of the cylinder $(D=26 \mathrm{~mm})$ current on the cylinder-cathode voltage in helium at $I_{a u x}=10 \mathrm{~mA}$. $1-P=0.3$ Torr., $2-P=0.5$ Torr., $3-P=0.8$ Torr.
Attempts to smoothly control the discharge current of a glow discharge using additional electrons, in particular, a grid placed in the discharge space, have been undertaken for a long time, but they were unsuccessful due to screening of the grid field after the discharge was ignited [5]. To prevent the grid from losing its control action after the discharge ignition, it is necessary to place it in the region of a unipolar space charge, as is done, for example, in electron guns with a high-voltage discharge in a cold hollow cathode [6]. In a glow discharge, the grid could continuously control the discharge current if it was placed in the region of the cathode dark space; however, the width of this region is small and changes sharply with changes in both the gas pressure and the discharge current; therefore, the operation of such devices will be unstable.

The task of controlling the discharge current when using a hollow cathode is simplified because a hollow cathode device can operate at a lower gas pressure than a flat cathode device. In this case, the width of the cathode dark space is quite large and weakly depends on the gas pressure, in the region of optimal pressures. The injection of electrons from the auxiliary discharge into the cathode cavity leads to a decrease in the cathode potential drop or, if this value is kept constant, to an increase in the current in a hollow cathode discharge.

\section{DISCUSSIONS}

In addition to controlling the main discharge current over a wide range, current amplification is also possible when electrons are injected into a hollow cathode glow discharge. After igniting the discharge, electrons from the anode region of the auxiliary discharge penetrate through the holes in the grid into the cathode cavity of a hollow cathode discharge and, having accelerated in the cathode dark space, ionize gas atoms along with electrons escaping from the cathode as a result of $\gamma$-processes [7]. Formed due to the ionization of the gas by the injected electrons additional ions knock out new electrons from the cathode, which results in amplification of current of electrons flowing into the cathode cavity.

Let us write down the boundary conditions on the inner surface of the grid cathode with the auxiliary discharge turned off:

$$
j_{o}=j_{e o}+(1-\alpha) j_{i o}
$$

where $j_{o}$ is the current density of the main discharge; $j_{e o}$ and $j_{i o}$ are the densities of electron and ion currents at the cathode; $\alpha$ is transparency of the grid cathode. The electron and ion currents at the cathode are related by the secondary emission coefficient $\gamma$ :

$$
j_{e o}=\gamma j_{i o}
$$

then one can write:

$$
j_{o}=j_{e o}\left(1+\frac{1-\alpha}{\gamma}\right)
$$

When the auxiliary discharge is turned on, an additional electronic current will come out of the cathode, which we

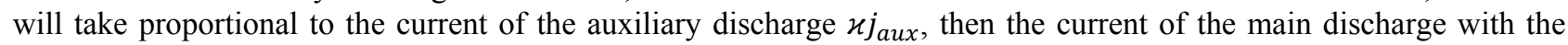
auxiliary discharge turned on is:

$$
j_{o}^{\prime}=\left(i_{e o}+\varkappa j_{a u x}\right)\left(1+\frac{1-\alpha}{\gamma}\right)=j_{o}+\varkappa j_{a u x}\left(1+\frac{1-\alpha}{\gamma}\right)
$$

where $\mathcal{u}$ is the factor showing what part of the auxiliary discharge current penetrates into the grid cavity.

The current gain is determined from the expression:

$$
k_{i}=\frac{j_{o}}{j_{\text {aux }}}=\varkappa\left(1+\frac{1-\alpha}{\gamma}\right) .
$$

The dependence of the current gain on the discharge mode is mainly contained in the factor $\varkappa$, the value of which is difficult to calculate, since it depends on the conditions both in the auxiliary discharge and in the main discharge cathode region. Measurement of the plasma concentration in the auxiliary discharge shows that a negative anodic potential drop should be observed in it. With an increase in the main discharge current, the field that draws electrons from the auxiliary discharge anode region increases, so the gain increases. Thus, the injection of electrons from the auxiliary discharge into 
the cathode cavity makes it possible to smoothly control the current of a hollow cathode glow discharge, and it is possible to amplify the current of injected electrons. The selection of the physical conditions of the discharge (configuration and dimensions of the electrodes, the material of the cathode and the type of gas), possibly, will make it possible to optimize the parameters of the device so that it can find practical application due to the advantages inherent in gas-discharge devices with a cold cathode.

\section{CONCLUSIONS}

1. The possibility of a significant (3-5 times) reduction in the cathode potential drop of a hollow cathode discharge due to the injection of electrons from an auxiliary discharge into the cathode cavity is shown.

2. As a result of injection of electrons from the auxiliary discharge, the increase in the main discharge current is 510 times higher than one for the auxiliary discharge current.

3. The injection of electrons into the cathode cavity at a fixed current of the main discharge leads to an increase in the plasma concentration in the cathode cavity and a decrease in the width of the cathode dark space.

4. The injection of electrons from the auxiliary discharge into the cathode cavity makes it possible to smoothly control the current of the hollow cathode glow discharge.

\section{ORCID IDs}

(1DStanislav V. Pogorelov, https://orcid.org/0000-0002-0189-8655; (DVolodymyr A. Timaniuk, https://orcid.org/0000-0003-0689-6074

(D)Nikolay G. Kokodii, https://orcid.org/0000-0003-1325-4563; (DIhor V. Krasovskyi, https://orcid.org/0000-0003-4585-7377

\section{REFERENCES}

[1] N.V. Gavrilov, and A.S. Kamenetskikh, ZhTF, 77(3), 12-16 (2007), https://journals.ioffe.ru/articles/viewPDF/9070. (in Russian)

[2] A. S. Klimov, and S.A. Ostanin, Proceedings of TUSUR University, 20(4), 26-29 (2017), https://doi.org/10.21293/1818-04422017-20-4-26-29. (in Russian)

[3] N.V. Gavrilov, D.R. Emlin, and A.S. Kamenetskikh, Tech. Phys. 53, 1308-1313 (2008), https://doi.org/10.1134/S1063784208100083.

[4] V.V. Denisov, Y.K. Akhmadeev, N.N. Koval, I.V. Lopatin, and E.V. Ostroverkhov, Russ. Phys. J. 62, 563-568 (2019), https://doi.org/10.1007/s11182-019-01747-3.

[5] B.I. Moskalev, Разряд с полым катодом [Hollow cathode discharge], (Energiya, Moscow, 1969), pp. 184. (in Russian)

[6] A.S. Metel, S.N. Grigoriev, Yu.A. Melnik, and V.P. Bolbukov, Instruments and Experimental Techniques, 55, 122-130 (2012), https://doi.org/10.1134/S0020441211060170.

[7] V.A. Timanyuk, N.G. Kokodiy, and F.G. Diaghileva, Papers SWORLD Transport, Engineering, Physics and Mathematics, 2(46), 95-100 (2017), https://www.sworld.com.ua/ntsw/117-2.pdf. (in Russian)

[8] C. Yuan, A.A. Kudryavtsev, A.I. Saifutdinov, S.S. Sysoev, R. Tian, J. Yao, and Zh. Zhou. IEEE Transactions on Plasma Science, 45, 3110-3113 (2017), https://doi.org/10.1109/TPS.2017.2758170

[9] V.A. Lisovskiy, D.I. Khilko, R.O. Osmayev, and V.D. Yegorenkov. Eur. J. Phys. 40, 045203 (2019), https://doi.org/10.1088/1361-6404/ab1a59.

\section{ВПЛИВ ІНЖЕКЦІЇ ЕЛЕКТРОНІВ НА ХАРАКТЕРИСТИКИ ТЛІЮЧОГО РОЗРЯДУ ПОРОЖНИСТОГО КАТОДУ

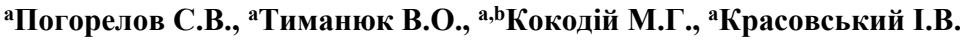 ${ }^{a}$ Національний фармачевтичний університет, Харків, Украйна \\ ${ }^{\text {} Х а р к і в с ь к и и ̆ ~ н а ц і о н а л ь н и и ̆ ~ у н і в е р с и т е т ~ і м е н і ~ В . Н . ~ К а р а з і н а, ~ Х а р к і в, ~ У к р а и ̈ н а ~}$}

У статті представлені результати експериментальних досліджень тліючого розряду з порожнистим катодом в атмосфері гелію та аргону з використанням допоміжного розряду в якості електронного емітера. Автори запропонували зробити електрод у вигляді циліндричної металевої сітки загальним для обох розрядів. Переваги цієї конструкції пояснюються наступним чином. Зв'язок між розрядами здійснюється через отвори в сітці з геометричною прозорістю 0,2, що дає можливість не тільки плавно контролювати струм основного тліючого розряду, але і підсилювати струм цього розряду. Відомо, що одним 3 найефективніших електронних емітерів $\epsilon$ плазма; однак іiі використання в якості катода в приладах з тліючим розрядом при низькому тиску газу ускладнюється тим, що для відокремлення потоку електронів від плазми необхідна сітка 3 невеликими отворами, і недоцільно використовувати таку систему через малу механічну міцність сітки. Оскільки порожнистий катод ефективно працює при низькому тиску газу, виділення потоку електронів з плазми деякого допоміжного розряду можливо при значно більших отворах в сітці, що розділяе плазму і катодну порожнину. У цьому випадку сітку можна виготовити такою, щоб вона витримувала досить високі теплові навантаження і змогла працювати в типових режимах розряду 3 порожнистим катодом. Інжекція електронів у катодну порожнину тліючого розряду змінює радіальний розподіл інтенсивності світіння, ширину темного катодного простору та інші параметри плазми в катодній порожнині. Вплив електронів, що проникають із допоміжного розряду в катодну порожнину основного розряду, стає значним, коли струм цих електронів стає порівнянним або перевищує струм електронів, що вийшли 3 поверхні катода у вигляді сітки в результаті $\gamma$-процесів. Паралельно із вимірюванням оптичних та електричних характеристик плазми тліючого розряду 3 порожнистим катодом проводились вимірювання концентрації електронів методом мікрохвильового зондування. Весь струм допоміжного розряду проникає в порожнину основного розряду; однак, після прискорення в темному катодному просторі, електрони, що проникають із допоміжного розряду, іонізують атоми газу і помітно збільшують струм основного розряду. Додаткові іони, що утворюються внаслідок іонізації газу інжектованими електронами, вибивають нові електрони з поверхні катода, що дає можливість збільшити струм розряду.

КЛЮЧОВІ СЛОВА: тліючий розряд, плазма, порожнистий катод, електрони, інжекція. 